p-ISSN: 2774-1907; e-ISSN: 2774-1915; Volume 1, Nomor 1, Nopember 2020

\title{
PENGARUH PERPUSTAKAAN LORONG TERHADAP PEMBERDAYAAN MASYARAKAT PARANGTAMBUNG KOTA MAKASSAR
}

\section{THE EFFECT OF LORONG LIBRARY ON EMPOWERMENT OF PARANGTAMBUNG SOCIETY IN MAKASSAR CITY}

\author{
Rahman Rumaday ${ }^{1}$ \\ Kumunitas Anak \\ Pelangi (K-Apel) \\ Makassar $^{1}$ \\ email: \\ mamankosrad@gmail.c \\ om

\section{Anirwan $^{2}$ \\ Universitas Pancasakti Makassar $^{2}$ \\ email: \\ anirwan@unpacti.ac.id}

IJI Publication p-ISSN: 2774-1907 e-ISSN: 2774-1915 Vol.1, No.1, pp.1-10, Nopember 2020

Unit Publikasi Ilmiah Intelektual Madani Indonesia
Abstrak: Perpustakaan merupakan sebuah pusat informasi bagi masyarakat untuk menghimpun berbagai sumber informasi, mengelola, serta melestarikan dan menyebarluaskan informasi bagi seluruh masyarakat yang mempunyai peranan penting dalam proses memperluas wawasan dan mencerdaskan kehidupan bangsa. Pengadaan perpustakaan berbasis masyarakat merupakan faktor penting untuk meningkatkan pengetahuan masyarakat. Salah satu penyebab rendahnya kualitas pengetahuan masyarakat adalah kurangnya perpustakaan berbasis masyarakat yang dapat mendorong kegemaran masyarakat membaca dalam kehidupan sehari-hari. Hal ini berdampak negatif terhadap kemampuan masyarakat dalam mengembangkan dirinya untuk menambah ilmu melalui kegiatan membaca secara mandiri. Oleh karena itu, penelitian ini bertujuan untuk mengetahui Pengaruh Perpustakaan Lorong Terhadap Pemberdayaan Masyarakat Lorong di Kelurahan Parang Tambung Kecamatan Tamalate Kota Makassar. Penelitian ini menggunakan metode kuantitatif dengan pendekatan survei. Penarikan sampel dilakukan dengan teknik Random Samping. Data hasil penelitian dianalisis dengan menggunakan SPSS dengan teknik analisis data dilakukan melalui Uji Asumsi Klasik dan Analisis Regresi Sederhana. Hasil penelitian menunjukkan bahwa keberadaan perpustakaan lorong berpengaruh positif dan signifikan terhadap pemberdayaan masyarakat lorong 7 Jalan Dg. Tata 3, Kelurahan Parang Tambung Kecamatan Tamalate Kota Makassar dengan nilai koefesien 0,419 dan probabilitas (Sig.) 0,025. Maka hipotesis Ho ditolak dan Ha diterima. Dan apabila fasilitas perpustakaan meningkat sebesar $1 \%$ maka akan terjadi peningkatan pemberdayaan masyarakat sebesar 0,419 karena perpustakaan lorong memiliki proporsi pengaruh terhadap pemberdayaan masyarakat lorong sebesar $29,5 \%$ sedangkan sisanya $70,5 \%$ dipengaruhi oleh variabel lain yang tidak diteliti. Olehnya itu, direkomendasikan agar pemerintah memberi dukungan kepada pengelola perpustakaan lorong dengan meningkatkan fasilitas perpustakaan.

Kata Kunci: Perpustakaan Lorong; Pemberdayaan; Masyarakat.

Abstract: The library is an information center for the community to collect various sources of information, manage, preserve and disseminate information to all people who have an important role in the process of broadening the horizons and educating the nation's life. The provision of community-based libraries is an important factor to increase public knowledge. One of the causes of the low quality of public knowledge is the lack of community-based libraries that can encourage people's penchant for reading in their daily lives. This has a negative impact on people's ability to develop themselves to increase their knowledge through reading activities independently. Therefore, this study aims to determine the effect of the Lorong Library on the Empowerment of the Lorong Community in Parang Tambung Village, Tamalate District, Makassar City. This study uses a quantitative method with a survey approach. Sampling was done using the Random Side technique. The research data were analyzed using SPSS with data analysis techniques performed through the Classical Assumption Test and Simple Regression Analysis. The results showed that the existence of the hallway library had a positive and significant effect on the empowerment of the community in the hall 7 Jalan Dg. Tata 3, Parang Tambung Village, Tamalate District, Makassar City with a coefficient value of 0.419 and a probability (Sig.) Of 0.000. Then the hypothesis Ho is rejected and $\mathrm{Ha}$ is accepted. And if the library facilities increase by $1 \%$, there will be an increase in community empowerment by 0.419 because the hallway library has a proportion of influence on the empowerment of the hallway community by $29.5 \%$ while the remaining $70.5 \%$ is influenced by other variables not studied. Therefore, it is recommended that the government provide support to the hallway library managers by improving library facilities.

Keywords: Alley Library; Empowerment; Community. 


\section{PENDAHULUAN}

Berbicara tentang pendidikan maka sangat erat kaitannya dengan peningkatan kualitas hidup manusia. Dan salah satu upaya yang dilakukan guna memperbaiki kualitas hidup Sumber Daya Manusia (SDM) adalah melalui pemberdayaan. Pemberdayaan adalah langkah untuk membuat manusia berdaya, memiliki semangat bekerja untuk memerangi kekurangan dan keterbelakangan masyarakat dengan harapan membangun diri mereka sendiri untuk lebih maju dan sejahtera.

Saat ini kemajuan perkembangan ilmu pengetahuan dan teknologi, semakin menuntut kebutuhan masyarakat agar dapat beradaptasi dengan kondisi tersebut. Tingkatan sosial yang paling kecil dalam rangka peningkatan kualitas SDM dapat dilakukan dimulai dari bidang pendidikan. Pendidikan memiliki arti penting bagi kehidupan masyarakat Indonesia. Pendekatan melalui pendidikan ini pada praktiknya di masyarakat banyak mengambil peran untuk pemberdayaan masyarakat.

Pada hakikatnya pendidikan masyarakat memiliki prioritas pada individu yang kurang beruntung dari segi ekonomi, geografis, dan sosial budaya. Artinya sasaran pendidikan masyarakat adalah mereka yang kurang beruntung karena belum memiliki kesempatan untuk mengembangkan keterampilan, pengetahuan, sikap, dan potensi diri yang dimiliki. Berkaitan dengan hal tersebut, salah satu langkah pemberdayaan masyarakat di bidang pendidikan adalah dengan menyediakan sarana untuk membaca atau perpustakaan. Perpustakaan merupakan sebuah pusat informasi bagi masyarakat, dimana perpustakaan bertugas untuk menghimpun berbagai sumber informasi, mengelolah, serta melestarikan dan menyebarluaskan informasi bagi seluruh masyarakat.

Perpustakaan mempunyai peranan penting dalam proses memperluas wawasan dan mencerdaskan kehidupan bangsa. Hal ini ditegaskan dalam Undang-Undang Perpustakaan No. 43 Tahun 2007. Dalam pasal 3 menyebutkan bahwa perpustakaan berfungsi berfungsi sebagai wahana pendidikan, penelitian, pelestarian, informasi, dan rekreasi untuk meningkatkan kecerdasan dan keberdayaan bangsa.". Dan penegasan tujuan perpustakaan juga dijelaskan pada undang-undang tersebut pada pasal 4 yang berbunyi: "Perpustakaan bertujuan memberikan layanan kepada pemustaka, meningkatkan kegemaran membaca, serta memperluas wawasan dan pengetahuan untuk mencerdaskan kehidupan bangsa."

Pengadaan perpustakaan berbasis masyarakat merupakan faktor penting untuk meningkatkan pengetahuan masyarakat. Salah satu penyebab rendahnya kualitas pendidikan masyarakat Indonesia adalah kurangnya perpustakaan berbasis masyarakat yang dapat mendorong kegemaran masyarakat membaca dalam kehidupan sehari-hari. Hal ini mempunyai dampak negatif terhadap kemampuan mereka dalam mengembangkan dirinya untuk menambah ilmu melalui kegiatan membaca secara mandiri.

Sebagai tindak lanjut dalam pengembangan kualitas sumber daya manusia tersebut dan merupakan program yang ada di Kota Makassar, Lembaga Pemberdayaan Masyarakat (LPM) mempelopori beberapa pembentukan Perpustakaan Lorong di beberapa titik kecamatan di Kota Makassar, salah satunya perpustakaan lorong yang terletak di lorong 7. Hal ini sejalan dengan amanat Peraturan Daerah Kota Makassar Nomor 41 Tahun 2001 Tentang Pedoman Pembentukan Lembaga Pemeberdayaan Masyarakat Dalam Daerah Kota Makassar yang menyatakan bahwa pembentukan LPM dimaksudkan sebagai wadah partisipasi masyarakat yang lebih bernuansa pemberdayaan masyarakat. 
Pembentukan perpustakaan lorong di lorong 7 tentu akan membawa pengaruh terhadap pemberdayaan masyarakat yang ada di lorong 7. Oleh karena itu, tujuan penelitian ini adalah untuk mengetahui Pengaruh Perpustakaan Lorong Terhadap Pemberdayaan Masyarakat Lorong di Kelurahan Parang Tambung Kecamatan Tamalate Kota Makassar.

\section{METODE}

Penelitian menggunakan metode kuantitatif dengan pendekatan survei. Populasi penelitian ini adalah seluruh warga lorong 7 Dg.Tata 3, Parang Tambung Kecamatan Tamalate Makassar dengan penarikan sampel dilakukan dengan teknik Random Samping. Data hasil penelitian dianalisis dengan menggunakan SPSS dengan teknik analisis data dilakukan melalui Uji Asumsi Klasik dan Analisis Regresi Sederhana.

Hipotesis penelitian ini adalah Perpustakaan Lorong berpengaruh signifikan terhadap Pemberdayaan Masyarakat di lorong 7 Dg.Tata 3, Parang Tambung Kecamatan Tamalate Makassar, dengan hubungan korelasi dinyatakan :

Ho: Tidak ada hubungan (korelasi) antara dua variabel.

Ha: Ada hubungan (korelasi) antara dua variabel.

\section{HASIL DAN DISKUSI}

Penelitian ini memberikan gambaran terkait pengaruh perpustakaan lorong terhadap pemberdayaan masyarakat lorong di Kelurahan Parang Tambung Kecamatan Tamalate Kota Makassar. Penelitian ini terdiri dari dua variabel yaitu perpustakaan lorong sebagai variabel bebas dan pemberdayaan masyarakat sebagai variabel terikat.

\section{Deskripsi Variabel Perpustakaan Lorong} (X)

Perpustakaan adalah tempat untuk mengembangkan informasi dan pengetahuan yang dikelola oleh suatu lembaga pendidikan, sekaligus sebagai sarana edukatif untuk membantu memperlancar cakrawala pendidik dan peserta didik dalam kegiatan belajar mengajar.

Adapun tanggapan responden terkait perpustakaan lorong adalah sebagai berikut :

Tabel 1

Tanggapan Mengenai Perpustakaan Lorong Memiliki Koleksi Buku yang Lengkap

\begin{tabular}{|c|c|c|c|}
\hline No & Indikator & Frekuensi & Persentase \\
\hline 1. & Sangat Setuju & 12 & 8,4 \\
\hline 2. & Setuju & 31 & 21,7 \\
\hline 3. & Cukup Setuju & 21 & 14,7 \\
\hline 4. & Kurang Setuju & 6 & 4,9 \\
\hline 5. & Tidak Setuju & 0 & 0 \\
\hline \multicolumn{2}{|r|}{ Juman } & 70 & $100 \%$ \\
\hline
\end{tabular}
Sumber: Olahan data, 2019

Tabel diatas menunjukkan bahwa Perpustakaan lorong memiliki koleksi buku yang lengkap mulai dari buku pelajaran, fiksi hingga non fiksi, sebanyak 12 responden $(8,4 \%)$ menyatakan Sangat Setuju sebanyak 31 responden $(21,7 \%)$ yang menyatakan Setuju, sebanyak 21 responden (14,7\%) menyatakan Cukup Setuju sebanyak 6 responden (4,9\%) menyatakan Kurang Setuju serta responden yang menyatakan Tidak Setuju 0 (0\%).

Berdasarkan data diatas maka dapat disimpulkan bahwa tanggapan responden terhadap kelengkapan koleksi buku di Perpustakaan lorong cukup baik, terlihat dari responden yang setuju dengan lengkapnya koleksi buku sebanyak 21,7\% atau sebanyak 31 orang bahkan ada yang sangat setuju sebanyak 12 orang atau $8,4 \%$ dan yang cukup setuju sebanyak 21 orang atau $14,7 \%$ walaupun masih adan yang merasa kurang setuju dengan pernyataan mengenai kelengkapan koleksi buku di Perpustakaan lorong sebanyak 6 orang atau 4,9\%.

Keberadaan bahan-bahan pustaka yang berkualitas serta variasi subjek yang cukup, 
memperluas kesempatan kepada para pemakainya untuk menambah pengetahauan masyarakat khususnya yang ada di lorong 7 Kelurahan Parang Tambung Kecamatan Tamalate Kota Makassar. Dan untuk tujuan tersebut, koleksi perpustakaan terdiri atas berbagai jenis bahan pustaka yang dipilih dengan seksama mengenai semua jenis koleksi dan tingkatan kemampuan kebutuhan masyarakat, melayani relawan-relawan yang ada diperpustakaan lorong tersebut yang ingin memberi pelajaran yang hidup, menarik dan praktis, guna melayani para masyarakat yang haus akan pengetahuan ingin mengembangkan jiwanya.

Tabel 2

Tanggapan Mengenai Perpustakaan Lorong Memiliki Dekorasi yang Menarik

\begin{tabular}{|c|c|c|c|}
\hline No & Indikator & Frekuensi & Persentase \\
\hline 1. & Sangat Setuju & 12 & 8,4 \\
\hline 2. & Setuju & 34 & 23,8 \\
\hline 3. & Cukup Setuju & 21 & 14,7 \\
\hline 4. & Kurang Setuju & 5 & 3,5 \\
\hline 5. & Tidak Setuju & 0 & 0 \\
\hline & Jumlah & 70 & $100 \%$ \\
\hline
\end{tabular}

Sumber : Olahan data, 2019

Tabel diatas menunjukkan bahwa Perpustakaan lorong memiliki dekorasi yang menarik untuk meningkatkan minat baca, sebanyak 12 responden $(8,4 \%)$ menyatakan Sangat Setuju, sebanyak 34 responden (24,8\%) yang menyatakan Setuju, sebanyak 21 responden (14,7\%) menyatakan Cukup Setuju sebanyak 5 responden $(3,5 \%)$ menyatakan Kurang Setuju, serta responden yang menyatak Tidak Setuju $0(0 \%)$.

Dari data di atas maka penulis dapat menyimpulkan mengenai dekorasi Perpustakaan lorong apakah menarik atau tidak, sebagaian besar responden setuju bahwa dekorasi yang dimiliki perpustakaan lorong memang menarik terlihat dari responden yang setuju sebanyak 34 orang atau $23,8 \%$ hampir dari setengahnya responden, bahkan ada responden yang sangat setuju sebanyak 12 orang atau 8,4\% dan cukup setuju sebanyak 21 orang atau $14,7 \%$ responden. Tetapi masih ada yang menyatakan kurang setuju dengan pernyataan perpustakaan lorong memiliki dekorasi yang menarik yaitu sebanyak 5 orang atau 3,5\%.

Oleh karena itu ruang bagi perpustakaan merupakan hal penting setelah koleksi bahan pustaka. Dalam ruang-ruang perpustakaan pemustaka beraktivitas. Mereka bisa berlama-lama membaca atau mencari informasi yang mereka butuhkan. Ruangan yang nyaman akan menarik orang untuk datang ke perpustakaan. Tata ruang perpustakaan diyakini dapat mempengaruhi atau meningkatkan minat baca. Untuk itu perpustakaan memerlukan penataan atau desain tata ruang. Guna menyediakan ruang yang representatif untuk memfasilitasi orang membaca.

Tabel 3

Tanggapan Mengenai Perpustakaan Lorong Mudah Dijangkau Dan Tempatnya Startegis

\begin{tabular}{|c|c|c|c|}
\hline No & Indikator & Frekuensi & Persentase \\
\hline 1. & Sangat Setuju & 13 & 9,1 \\
\hline 2. & Setuju & 20 & 14 \\
\hline 3. & Cukup Setuju & 31 & 21,7 \\
\hline 4. & Kurang Setuju & 6 & 4,2 \\
\hline 5. & Tidak Setuju & 0 & 0 \\
\hline & Jumlah & 70 & $100 \%$ \\
\hline
\end{tabular}

Sumber : Olahan data, 2019

Tabel diatas menunjukkan bahwa Perpustakaan lorong mudah dijangkau masyarakat dan tempatnya startegis, sebanyak 13 responden $(9,1 \%)$ menyatakan Sangat Setuju, sebanyak 20 responden (14\%) yang menyatakan Setuju, sebanyak 31 responden $(21,7 \%)$ menyatakan Cukup Setuju sebanyak 6 responden (4,2\%) menyatakan Kurang Setuju, serta responden yang menyatak Tidak Setuju 0 (0\%).

Dari data di atas maka penulis dapat menyimpulkan bahwa Perpustakaan lorong mudah dijangkau masyarakat dan tempatnya startegis sebagaian besar responden setuju bahwa perpustakaan lorong memang muda dijangkau dan tempatnya sangat strategis terlihat dari responden yang sangat setuju sebanyak 13 orang atau 9,1\% respoden yang menyatakan Setuju 20 orang atau 14\%, respoden yang menyatakan Cukup Setuju 31 
orang atau $21,7 \%$ hampir dari semua responden, merespon positif mengenai perpustakaan lorong 7 mudah dijangkau masyarakat dan tempatnya startegis dibanding dengan yang kurang setu dan tidak setuju masing-masing responden menyatakan Kurang Setuju responden atau 4,2\%, serta responden yang menyatak Tidak Setuju 0 atau $0 \%$.

Dari keterangan di atas bahwa sebagian masyarakat mengatakan bahwasanya perpustakaan lorong sudah merupakan bagian dari kebutuhannya yang harus dipenuhi untuk menujang aktifitasnnya. sehingga ketersediaan dan kemudahan akses yang dibutuhkan, masyarakat tentunya akan mengalami kesulitan apabila tempatnya yang berada di posisi yang tidak sterategis sehingga tidak mudah di jangkau. Namun bagi sebagian masyarakat lain adalah hal sebaliknya. Hal tersebut tidak hanya disebabkan karena minat baca mereka yang masih rendah tetapi masih banyak faktor yang mempengaruhinya. Faktor tersebut salah satunya disebabkan karena keterbatasan akses untuk menjangkau perpustakaan lorong tersebut.

Tabel 4

Tanggapan Mengenai Perpustakaan Lorong Koleksi Buku Fiksi Dan Nonfiksi yang Up To Date

\begin{tabular}{|c|c|c|c|}
\hline No & Indikator & Frekuensi & Persentase \\
\hline 1. & Sangat Setuju & 8 & 5.6 \\
\hline 2. & Setuju & 35 & 24,5 \\
\hline 3. & Cukup Setuju & 22 & 15,4 \\
\hline 4. & Kurang Setuju & 5 & 3,5 \\
\hline 5. & Tidak Setuju & 0 & 0 \\
\hline \multicolumn{2}{|r|}{ Jumlah } & 70 & $100 \%$ \\
\hline
\end{tabular}

Sumber : Olahan data, 2019

Tabel diatas menunjukkan bahwa Perpustakaan lorong memiliki koleksi buku fiksi dan nonfiksi yang up to date (10 tahun terakhir), sebanyak 8 responden $(5,6 \%)$ menyatakan Sangat Setuju, sebanyak 35 responden $(24,5 \%)$ yang menyatakan Setuju, sebanyak 22 responden $(15,4 \%)$ menyatakan Cukup Setuju sebanyak 5 responden $(3,5 \%)$ menyatakan Kurang Setuju, serta responden yang menyatak Tidak Setuju $0(0 \%)$.
Dari data di atas maka penulis dapat menyimpulkan bahwa Perpustakaan lorong memiliki koleksi buku fiksi dan nonfiksi di yang up to date (10 tahun terakhir) sebagaian besar responden setuju bahwa perpustakaan lorong memang memiliki koleksi buku fiksi dan non fiksi yang up to date terlihat dari responden yang sangat setuju sebanyak 8 orang atau 5,6\% yang menyatakan Setuju sebanyak 35 orang atau $24,5 \%$, yang menyatakan Cukup Setuju, dan 22 orang atau $15,4 \%$, hampir dari semua responden, merespon positif mengenai perpustakaan lorong 7 koleksi yang up to date dibanding dengan yang kurang setu dan tidak setuju masing-masing responden menyatakan Kurang Setuju sebanyak 5 orang atau 3,5\%, serta yang menyatakan Tidak Setuju sebanyak 0 orang atau $0 \%$.

Tabel 5

Tanggapan Mengenai Perpustakaan Lorong Memiliki Tatanan Rak Buku yang Rapi

\begin{tabular}{|c|c|c|c|}
\hline No & Indikator & Frekuensi & Persentase \\
\hline 1. & Sangat Setuju & 4 & 2,8 \\
\hline 2. & Setuju & 40 & 28 \\
\hline 3. & Cukup Setuju & 18 & 12,6 \\
\hline 4. & Kurang Setuju & 8 & 5,6 \\
\hline 5. & Tidak Setuju & 0 & 0 \\
\hline \multicolumn{2}{|c|}{ Jumlah } & 70 & $100 \%$ \\
\hline
\end{tabular}

Sumber: Olahan data, 2019

Tabel diatas menunjukkan bahwa Perpustakaan lorong memiliki tatanan rak buku yang rapi sehingga memudahkan pembaca atau warga mencari buku yang diinginkan Sebanyak 4 responden (2,8\%) menyatakan Sangat Setuju, sebanyak 40 responden (28\%) yang menyatakan Setuju, sebanyak 18 responden $(12,6 \%)$ menyatakan Cukup Setuju sebanyak 8 responden $(5,6 \%)$ menyatakan Kurang Setuju, serta responden yang menyatak Tidak Setuju $0(0 \%)$.

Berdasarkan data di atas maka penulis dapat menyimpulkan Perpustakaan lorong memiliki tatanan rak buku yang rapi sehingga memudahkan pembaca atau warga mencari buku yang diinginkan. Sebagaian besar responden setuju bahwa perpustakaan lorong memang memiliki tatanan rak buku yang rapi 
sehingga memudahkan pembaca atau warga mencari buku yang diinginkan terlihat dari responden yang sangat setuju sebanyak 4 orang atau 2,8\% yang menyatakan Setuju sebanyak 40 orang $28 \%$, yang menyatakan Cukup Setuju sebanyak 18 orang atau 12,6 \%, hampir dari semua responden, merespon positif mengenai perpustakaan lorong 7 tatanan rak buku yang rapi dibanding dengan yang kurang setuju dan tidak setuju masingmasing responden menyatakan Kurang Setuju sebanyak 8 orang atau $5,6 \%$, serta responden yang menyatak Tidak Setuju sebanyak 0 atau $0 \%$.

Secara keseluruhan dari tabel diatas mengenai tanggapan responden terhadap Perpustakaan Lorong. Maka hasil tabulasi yang telah diolah oleh peneliti dapat disimpulkan bahwa jawaban yang cenderung beragam dengan segala bentuk pernyataan mengenai perpustakaan lorong.

Berdasarkan tanggapan responden yang memiliki nilai persentase terbesar yaitu tanggapan setuju sebesar 45,5\%, yang memiliki persentase terkecil yaitu tanggapan tidak setuju sebesar $0 \%$. Untuk tanggapan sangat setuju memiliki nilai persentase sebesar 14\%, tanggapan cukup setuju memiliki nilai persentase sebebsar $31,7 \%$ dan untuk tanggapan kurang setuju memiliki nilai percentase sebesar $8,8 \%$.

\section{Deskripsi Variabel Pemberdayaan (Y)}

Pemberdayaan masyarakat adalah suatu proses pembangunan yang mana masyarakat memiliki inisiatif untuk memulai proses aktivitas sosial dalam memperbaiki situasi dan konsisi pada diri sendiri. Pemberdayaan masyarakat hanya dapat terjadi apabila masyarakat ikut serta dalam berpartisipasi melakukan kegaiatan tersebut. Oleh karena pemberdayaan masyarakat merupakan upaya untuk meningkatkan harkat dan martabat lapisan masyarakat yang dalam kondisi sekarang tidak mampu untuk melepaskan diri dari perangkap kemiskinan dan keterbelakangan. Dengan kata lain, pemberdayaan adalah memampukan dan memandirikan masyarakat.

Adapun tanggapan responden terkait pemberdayaan adalah sebagai berikut :

\section{Tabel 6}

Tanggapan Mengenai Perpustakaan Lorong Mendorong Kesadaran Memperoleh Informasi

\begin{tabular}{|c|c|c|c|}
\hline $\mathrm{No}$ & Indikator & Frekuensi & Persentase \\
\hline 1. & Sangat Setuju & 8 & 5.6 \\
\hline 2. & Setuju & 33 & 23,1 \\
\hline 3. & Cukup Setuju & 22 & 15,4 \\
\hline 4. & Kurang Setuju & 7 & 4,9 \\
\hline 5. & Tidak Setuju & 0 & 0 \\
\hline & Jumlah & 70 & $100 \%$ \\
\hline
\end{tabular}

Sumber : Olahan data, 2019

Tabel diatas menunjukkan bahwa perpustakaan lorong mampu mendorong kesadaran masyarakat akan pentingnya memperoleh informasi dengan membaca sejumlah literature sebanyak 8 responden $(5,6 \%)$ menyatakan Sangat Setuju, sebanyak 33 responden $(23,1 \%)$ yang menyatakan Setuju, sebanyak 22 responden $(15,4 \%)$ menyatakan Cukup Setuju sebanyak 7 responden (4,9\%) menyatakan Kurang Setuju, serta responden yang menyatak Tidak Setuju $0(0 \%)$.

Dapat disimpulkan bahwa kehadiran perpustakaan lorong sangat berpengaruh pada masyarakat lorong 7 kelurahan parang tambung hal ini terlihat pada kuesioner yang tersebar pada responden menyatakan Sangat Setuju 8 orang atau $5,6 \%$, responden menyatakan setuju 33 orang atau $23,1 \%$ dan responden menyatakan Cukup Setuju 22 orang atau 15,4\%. Dari 70 responden yang tersebar dibandingkan dengan responden yang menyatakan kurang setuju, dan tidak setuju. Sehubungan dengan hal tersebut sebagiaman inisiatif lahirnya perpustakaan lorong 7 ini bahwa

Perpustakaan bisa melahirkan banyak ide. Untuk mendorong kesadaran masyarakat akan pentingnya memperoleh informasi dengan membaca sejumlah literatur maka layanan di perpustakaan idealnya dapat lebih memikat, bersahabat, cepat, dan akurat, ini 
berarti orientasi pelayanan perpustakaan harus didasarkan pada kebutuhan pengguna, antisipasi perkembangan teknologi informasi dan pelayanan yang ramah, dengan kata lain menempatkan pengguna/masyarakat sebagai salah satu faktor penting yang mempengaruhi kebijakan pada suatu perpustakaan, kesan kaku pelayanan diperpustakaan harus dieliminir sehingga perpustakaan berkesan lebih manusiawi.

Tabel 7

Tanggapan Mengenai Perpustakaan Lorong Memperbanyak Koleksi dapat

Meningkatkan Minat Baca Masyarakat

\begin{tabular}{|c|c|c|c|}
\hline No & Indikator & Frekuensi & Persentase \\
\hline 1. & Sangat Setuju & 20 & 14 \\
\hline 2. & Setuju & 18 & 12,6 \\
\hline 3. & Cukup Setuju & 24 & 16,8 \\
\hline 4. & Kurang Setuju & 8 & 5,6 \\
\hline 5. & Tidak Setuju & 0 & 0 \\
\hline & Jumlah & 70 & $100 \%$ \\
\hline
\end{tabular}

Sumber : Olahan data, 2019

Tabel diatas menunjukkan bahwa perpustakaan lorong memperbanyak koleksi buku, majalah dan koran dapat meningkatkan minat baca masyarakat Responden yang menyatakan Sangat Setuju sebanyak 20 responden (14\%), Responden yang menyatakan Setuju, sebanyak 18 responden (12,8\%), Responden yang menyatakan Cukup Setuju sebanyak 24 responden (16,8\%), Responden yang menyatakan Kurang Setuju, 8 responden $(5,6 \%)$ serta responden yang menyatak Tidak Setuju $0(0 \%)$.

Pada poin ini dapat disimpulkan bahwa perpustakaan memiliki banyak koleksi buku, majalah dan koran dapat meningkat minat baca pada masyarakat, hal ini dapat di lihat pada jawaban responden yang menyatakan Sangat Setuju 20 orang (14\%), responden menyatakan setuju 18 orang $(12,8 \%)$ dan responden menyatakan Cukup Setuju 24 orang $(16,8 \%)$ dari 70 responden yang tersebar dibandingkan dengan responden yang menyatakan kurang setuju, dan tidak setuju.
Oleh karna karene itu minat seseorang banyak dipengaruhi oleh faktor internal seperti pemusatan perhatian, keinginan, motivasi, dan kebutuhan. Minat adalah suatu rasa lebih suka dan rasa keterikatan pada suatu hal atau aktivitas, tanpa ada yang menyuruh. Minat pada dasarnya adalah penerimaan akan suatu hubungan antara diri sendiri dengan sesuatu di luar diri. Semakin kuat atau semakin besar hubungan tersebut, maka semakin besar pula minat yang timbul. Suatu minat dapat diekspresikan melalui suatu pernyataan yang menunjukkan bahwa seseorang lebih menyukai suatu hal dari pada hal lainya, dapat pula dimanifestasikan melalui partisipasi dalam suatu aktivitas. Seseorang yang memiliki minat terhadap obyek tertentu cenderung untuk memberikan perhatian yang lebih besar terhadap obyek tersebut. Minat tidak dibawa sejak lahir, melainkan diperoleh kemudian. Minat terhadap sesuatu dipelajari dan mempengaruhi penerimaan minat-minat baru. Jadi minat terhadap sesuatu merupakan hasil belajar dan merencanakan belajar selanjutnya.

Tabel 8

Tanggapan Mengenai Perpustakaan Lorong Memberikan Keleluasan Warga Memperoleh Informasi

\begin{tabular}{|c|c|c|c|}
\hline No & Indikator & Frekuensi & Persentase \\
\hline 1. & Sangat Setuju & 17 & 11,9 \\
\hline 2. & Setuju & 16 & 11,2 \\
\hline 3. & Cukup Setuju & 35 & 24,5 \\
\hline 4. & Kurang Setuju & 2 & 1,4 \\
\hline 5. & Tidak Setuju & 0 & 0 \\
\hline \multicolumn{2}{|c|}{ Jumlah } & 70 & $100 \%$ \\
\hline
\end{tabular}

Sumber: Olahan data, 2019

Tabel diatas menunjukkan bahwa Perpustakaan lorong memberikan keleluasan khususnya warga untuk memperoleh informasi sebanyak-banyaknya, responden yang menyatakan Sangat Setuju sebanyak 17 responden (11,9\%), Responden yang menyatakan Setuju, sebanyak 16 responden (11,2\%), Responden yang menyatakan Cukup Setuju sebanyak 35 responden (24,5\%), Responden yang menyatakan Kurang Setuju, 
2 responden $(1,4 \%)$ serta responden yang menyatak Tidak Setuju 0 (0\%).

Berdasarkan data diatas dapat disimpulkan Bahwa perpustakaan lorong 7 parangtambung sebagai pusat menyimpan dan menyediakan informasi yang sebanyakbanyaknya kepada masyarakat lorong 7 parangtambung sehingga masyarakat dengan muda memperoh informasi masalah politik, pendidikan, budaya, ekonomi dan lain-lain termasuk yang berhubungan dengan denagn pemberdayaan masyarakat. Hal ini terlihat pada kuesioner yang tersebar pada responden yang menyatakan Sangat Setuju 17 orang $(11,9 \%)$, responden menyatakan setuju 16 orang $(11,2, \%)$ dan responden menyatakan Cukup Setuju 35 orang $(24,5 \%)$ dari 70 responden yang tersebar dibandingkan dengan responden yang menyatakan kurang setuju, dan tidak setuju.

Oleh karena itu bahwa perpustakaan sebagai suatu tempat/lembaga penyedia informasi yang memiliki peranan penting untuk menyediakan dan melayaniwarga dalam memperoleh informasi secara tepat, mudah, efektif dan efisien. Maka para relawan yang melayani warga perlu melakukan pelayanan yang ramah dan hangat tentu akan disukai para warga yang ada di Kelurahan Parang Tambung Kecamatan Tamalate Kota Makassar khususnya warga yang ada di sekitar perpustakaan lorong.

Secara keseluruhan dari tabel diatas mengenai tanggapan responden terhadap pemberdayaan masyarakat. Maka hasil tabulasi yang telah diolah oleh peneliti dapat disimpulkan bahwa jawaban yang cenderung beragam dengan segala bentuk pernyataan mengenai pemberdayaan masyarakat. Berdasarkan tanggapan responden yang memiliki nilai persentase terbesar yaitu tanggapan cukup setuju sebesar $38,5 \%$, yang memiliki persentase terkecil yaitu tanggapan tidak setuju sebesar $0 \%$. Untuk tanggapan sangat setuju memiliki nilai persentase sebesar 21,4\%, tanggapan setuju memiliki nilai persentase sebesar $32 \%$ dan untuk tanggapan kurang setuju memiliki nilai persentase sebesar $8,1 \%$.

\section{Pengaruh Perpustakaan Lorong (X) Terhadap Pemberdayaan Masyarakat (Y)}

Perpustakaan lorong adalah salah satu unit kerja yang berlokasi di dalam lorong yang berupa tempat pengumpulan, menyimpan dan memelihara koleksi bahan pustaka yang dikelola secara sistematis dengan cara tertentu, untuk digunakan secara berkelanjutan oleh pemustaka sebagai sumber informasi. Kehadiran perpustakaan lorong lorong 7 Dg.Tata 3, Parang Tambung Kecamatan Tamalate Makassar memberdayakan masyarakat dalam meningkatkan kualitas pengetahuan masyarakat.

Analisis korelasi menghasilkan koefesien korelasi pengaruh variabel perpustakaan lorong (X) terhadap pemberdayaan masyarakat (Y) di lorong 7 Dg.Tata 3, Parang Tambung Kecamatan Tamalate Makassar sebesar 0,419 dengan nilai konstanta sebesar 3,316 dan signifikansi 0,025 . Ini menjelaskan bahwa variabel perpustakaan lorong (X) memiliki pengaruh linear dan positif (searah) yang sangat signifikan terhadap pemberdayaan masyarakat (Y) di lorong 7 Dg.Tata 3, Parang Tambung Kecamatan Tamalate Makassar. Koefisien korelasi tersebut menunjukan bahwa setiap kenaikan perpustakaan lorong (X) sebesar satu satuan, akan meningkatkan skor pemberdayaan masyarakat (Y di lorong 7 Dg.Tata 3, Parang Tambung Kecamatan Tamalate Makassar sebesar 0,419 satuan; sebaliknya, setiap penurunan skor perpustakaan lorong (X) sebesar satu satuan, akan menurunkan skor pemberdayaan masyarakat (Y) di lorong 7 Dg.Tata 3, Parang Tambung Kecamatan Tamalate Makassar sebesar 0,419 satuan pada taraf signifikansi 0,025, dengan asumsi faktor-faktor lain yang mempengaruhi pemberdayaan masyarakat (Y) di lorong 7 
Dg.Tata 3, Parang Tambung Kecamatan Tamalate Makassar dianggap tidak konstan.

Hasil uji koefisien determinasi menunjukkan bahwa Koefisien determinasi sebesar 0,080, mengindikasikan bahwa kontribusi variabel Perpustakaan lorong (X) terhadap variasi tinggi rendahnya pemberdayaan masyarakat (Y) di lorong 7 Dg.Tata 3, Parang Tambung Kecamatan Tamalate Makassar sebesar 29,5\% persen, selebihnya 70,5 \% dipengaruhi variabelvariabel lainnya yang tidak diteliti dalam penelitian ini. Berdasarkan hasil analisis regresi sederhana diketahui bahwa variabel perpustakaan lorong memiliki koefisien regresi sebesar 0,419 dengan nilai signifikan 0,025 nilai tersebut menunjukkan jika variabel perpustakaan lorong meningkat $1 \%$ maka pemberdayaan masyarakat lorong akan meningkat sebesar $41,9 \%$. Hal ini berarti perpustakaan lorong memiliki hubungan positif terhadap pemberdayaan masyarakat lorong, yang jika variabel perpustakaan lorong meningkat menunjukkan pemberdayaan masyarakat lorong juga meningkat sehingga dapat meningkatkan minat baca masyarakat serta kesadaran akan pentingnya informasi. Nilai signifikan dari variabel independen adalah 0,025 lebih kecil dari probabilitas 0,05 sehingga dapat disimpulkan bahwa Ho ditolak dan $\mathrm{Ha}$ diterima, yang berarti bahwa terdapat pengaruh antara perpustakaan lorong terhadap pemberdayaan masyarakat. Nilai $t$ variabel perpustakaan lorong menunjukkan angka positif terhadap pemberdayaan masyarakat. Hal ini dapat dijelaskan bahwa perpustakaan lorong secara parsial berpengaruh terhadap pemberdayaan masyarakat.

Dengan demikian, dapat disimpulkan bahwa semakin tinggi skor perpustakaan lorong (X) akan menyebabkan skor pemberdayaan masyarakat (Y) di lorong 7 Dg.Tata 3, Parang Tambung Kecamatan Tamalate Makassar juga cenderung semakin tinggi. Sebaliknya, semakin rendah skor perpustakaan lorong (X) akan menyebabkan skor pemberdayaan masyarakat (Y) di lorong
7 Dg.Tata 3, Parang Tambung Kecamatan Tamalate Makassar juga cenderung semakin rendah.

Dari hasil analisis data penelitian, dapat disimpulkan bahwa variabel perpustakaan lorong (X) akan menyebabkan skor pemberdayaan masyarakat (Y) di lorong 7 Dg.Tata 3, Parang Tambung Kecamatan Tamalate Makassar, berpengaruh signifikan baik simultan (bersama-sama) maupun secara parsial. Dengan demikian, hipotesis dalam penelitian ini yang menyatakan bahwa perpustakaan lorong terhadap pemberdyaan masyarakat di lorong 7 Dg.Tata 3, Parang Tambung Kecamatan Tamalate Makassar, dengan ini dinyatakan diterima.

Dapat diketahui bahwa perpustakaan lorong di lorong 7 Dg.Tata 3, Parang Tambung Kecamatan Tamalate Makassar berada pada kategori baik. Keberadaan perpustakaan lorong memiliki pengaruh signifikan terhadap pemberdayaan masyarakat di lorong tersebut.

\section{KESIMPULAN}

Pengaruh perpustakaan lorong terhadap pemberdayaan masyarakat dapat dilihat dari hasil uji regresi linier sederhana menunjukkan bahwa perpustakaan lorong berpengaruh positif dan signifikan terhadap pengembangan masyarakat khususnya warga lorong 7 jalan Dg.Tata 3, Kelurahan Parang Tambung, Kecamatan Tamalate Kota Makassar, dengan nilai koefesien 0,419 dan probabilitas (Sig.) 0,025. Maka hipotesis Ho ditolak dan $\mathrm{Ha}$ diterima. Dan apabila fasilitas perpustakaan meningkat sebesar $1 \%$ maka akan terjadi peningkatan pemberdayaan masyarakat sebesar 0,419 karena perpustakaan lorong memiliki proporsi pengaruh terhadap pemberdayaan masyarakat lorong sebesar $29,5 \%$ sedangkan sisanya $70,5 \%$ dipengaruhi oleh variabel lain yang tidak diteliti. Olehnya itu, direkomendasikan agar pemerintah memberi dukungan kepada pengelola perpustakaan lorong dengan meningkatkan 
fasilitas perpustakaan. Salah satunya yaitu menyediakan kelas pengembangan diri yang bisa berdampak pada pemberdayaan masyarakat, misal memfasilitasi kelas kerajinan atau kelas ekonomi kreatif. Dan disarankan bagi peneliti selanjutnya dapat mengeksplorasi terkait manajemen perpustakaan lorong.

\section{REFERENSI}

Anwas M. Oos. 2014. Pemberdayaan Masyarakat Di Era Global. Bandung, Penerbit ALFABETA, Ed. 2.

Bambang Hudayana, 2017. Pemberdayaan Masyarakat. Yogyakarta, Pustaka Pelajar, Ed. 1.

Darmono. 2006. Manajemen dan Tata Kerja Perpustakaan Sekolah. Jakarta, Gramedia Widia Sarana Indonesia.

Edi Suharto. 2005. Membangun Masyarakat Memberdayakan Rakayat Kajian Strategis Pembangunan Kesejahteraan Sosial Dan Pekerja Sosial. Bandung, PT Ravika Adimatama Cet Ke-1. 2010. Membangun Masyarakat Memberdayakan Rakyat: Kajian Strategis Pembangunan Kesejahteraan Sosial dan Pekerjaan Sosial. Bandung, PT. Refika Aditama, Cet. Ke-4.

Isbandi R.A. 2008. Intervensi Komunitas Pengembangan Masyarakat sebagai Upaya Pemberdayaan Masyarakat. Jakarta, PT. Rajawali Pers, Ed. 1.

Rita Pranawati dan Irfan Abubakar. 2009. Pemberdayaan Masyarakat untuk Pembangunan Perdamaian. Jakarta, Center for the Study of Religion and Culture (CSRC) Universitas Islam Negeri (UIN) Syarif Hidayatullah Jakarta, Cet. Ke-1.

Rosmedi dan Risyanti, R 2006. Pemberdayaan Masyarakat. Sumedang, Alqaprit Jatinegoro.

Soetomo. 2002. Keswadayaan Masyarakat Manifestasi Kapasitas Masyarakat Untuk
Berkembang Secara Mandiri. Yogyakarta, Pustaka Pelajar, Ed. 1.

Soetomo. 2015. Pemberdayaan Masyarakat. Yogyakarta, Pustaka Pelajar, Ed. 3

Stian Haklev. 2008. Mencerdaskan Bangsa Suatu Pertanyaan Fenomena Taman Baca di Indonesia. Creative CommonsAttribution.

Sulistyo Basuki. 2003. Pengantar Ilmu Perpustakaan. Jakarta, Universitas Terbuka

Syafaruddin, P.R 2012. Pendidikan \& Pemberdayaan Masyarakat. Sumatera Utara, Perdana Publishing.

Wahyu Suprianto. 2008. Teknologi Informasi Perpustakaan. Yogyakarta, Kanisius.

Undang-Undang Nomor 43 Tahun 2007 Tentang Perpustakaan.

Peraturan Daerah Kota Makassar Nomor 41 Tahun 2001 Tentang Pedoman Pembentukan Lembaga Pemeberdayaan Masyarakat Dalam Daerah Kota Makassar. 